\title{
Immunological perspectives in thoracic surgery: a narrative review on the cellular and cytokine responses induced by thoracotomy and video-assisted thoracic surgery
}

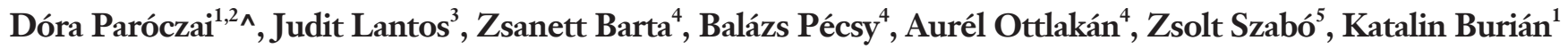 \\ ${ }^{1}$ Department of Medical Microbiology, University of Szeged, Szeged, Hungary; ${ }^{2}$ Department of Pulmonology, University of Szeged, Deszk, \\ Hungary; ${ }^{3}$ Department of Neurology, Bács-Kiskun County Hospital, Kecskemét, Hungary; ${ }^{4}$ Department of Surgery, University of Szeged, Szeged, \\ Hungary; ${ }^{5}$ Institute of Surgical Research, University of Szeged, Szeged, Hungary \\ Contributions: (I) Conception and design: D Paróczai, K Burián; (II) Administrative support: Z Barta, J Lantos; (III) Provision of study materials or \\ patients: B Pécsy, A Ottlakán, Z Szabó; (IV) Collection and assembly of data: D Paróczai; (V) Data analysis and interpretation: D Paróczai, B Pécsy, \\ A Ottlakán, K Burián; (VI) Manuscript writing: All authors; (VII) Final approval of manuscript: All authors. \\ Correspondence to: Dóra Paróczai, MD, PhD. Department of Pulmonology, University of Szeged, 6772 Deszk, Alkotmány str. 36. ., Hungary. \\ Email: paroczai.dora@med.u-szeged.hu.
}

Objective: To reveal and review the main effects of mechanical ventilation, anaesthesia, thoracotomy and thoracoscopy on immune responses and clinical outcomes.

Background: Several trials reported that intubated video-assisted thoracic surgery (VATS) is associated with favourable recovery time, hospital stay, fewer postoperative complications, better delivery and tolerability of adjuvant chemotherapy in patients with non-small cell lung cancer (NSCLC) as compared to traditional thoracotomy. Recent studies introduced a new approach in thoracic surgery focusing on the immunological outcomes and detrimental effects of thoracotomy and VATS along with patients' clinical benefits.

Methods: We reviewed main laboratory and human research based on PubMed database to reveal the immune effects of intubated and non-intubated VATS, mechanical one-lung ventilation (mOLV) and anaesthesia on inflammatory cytokine production, cell responses and clinical outcomes.

Conclusions: Although, there are still inconsistencies regarding whether VATS can improve long-term survival and immune responses. VATS results in better preserved immune functions: the postoperative number of natural killer (NK) cells, lymphocytes were less suppressed and the release of immunomodulatory interleukin (IL)-6 and IL-10 were reduced, compared to thoracotomy. Both thoracotomy and VATS are known to induce immune responses, however, these effects can be observed to a different extent as it depends on the modes of surgical technique, mOLV and even general anaesthesia. Thus, non-intubated thoracic surgery (NITS) was developed to avoid harmful immune effects, prevent acute lung injury (ALI) and increase patients' long-term survival. NITS could be also associated with less prominent pro-inflammatory cytokine responses and a preserved lymphocyte cell count postoperatively.

Keywords: Video-assisted thoracic surgery (VATS); non-intubated thoracic surgery (NITS); immune response; cytokine; natural killer cell (NK cell); lymphocyte

Received: 12 July 2021; Accepted: 15 November 2021; Published: 30 June 2022.

doi: 10.21037/asj-21-64

View this article at: https://dx.doi.org/10.21037/asj-21-64

$\wedge$ ORCID: 0000-0001-6792-6789. 


\section{Introduction}

Several studies proved that surgical trauma (such as surgical wound) and mechanical one-lung ventilation (mOLV) can trigger the release of damage-associated molecular patterns (DAMPs) that acts as the ligand of immune receptors and activate innate immune responses (1-3). The severity of further surgical consequences can be also influenced by the extent of surgical invasiveness, localisation, anaesthetic procedures and the patients' coexisting morbidities, infections or poor inadequate nutritional status. The advantages of video-assisted thoracic surgery (VATS) is well-recognized and some studies proved the superiority of VATS over open thoracotomy, because of the more favourable cytokine production, cellular responses, better cancer prognosis, reduced mortality or morbidity rates and the facilitation of the chemotherapy administration in nonsmall cell lung cancer (NSCLC) patients (4-7). However, mechanical ventilation technique is also a determining query in patients' well-being during VATS surgery as both the ventilated and collapsed lung could be affected by the ventilation modes (8).

Thus, we aimed to review both the latest clinical studies and laboratory researches reporting the cellular functions, cytokine responses and clinical outcomes influenced by intubated and non-intubated VATS, mechanical ventilation and anaesthesia. We present the following article in accordance with the Narrative Review reporting checklist (available at https://asj.amegroups.com/article/ view/10.21037/asj-21-64/rc).

\section{Methods}

All published articles pertaining to the clinical and immune effects of thoracotomy, intubated and non-intubated VATS surgery were collected by searching PubMed (MEDLINE) from the mid 1960s to 2021 using the following key words: acute lung injury, adjuvant chemotherapy, anaesthesia, animal model, cancer, cell response, cytokine, immune, infection, interleukin, intubated, lobectomy, lymphocyte, metastasectomy, natural killer (NK) cell, non-intubated thoracic surgery (NITS), oncological, one-lung ventilation, postoperative, pro-inflammatory, resection, surgery, thoracotomy, tumour necrosis factor, video-assisted surgery. Searches were augmented by manually reviewing the reference lists of all reviews, meta-analysis and original articles. The purpose of the following systematic review was neither to perform meta-analysis nor to grade the evidence of the used literature.

\section{Cellular, immune and inflammatory response to VATS as compared to open thoracotomy}

Surgical trauma is known to promote the release of acute phase proteins including $\mathrm{C}$-reactive protein (CRP) and several cytokines such as interleukin (IL)-1, -6 and tumour necrosis factor- $\alpha(\mathrm{TNF}-\alpha)$ could play a role in postoperative consequences. The level of IL-6 increased 1 hour after surgical trauma and peaked between 2 and 4 hours postoperatively, hence elevating the risk of further lung injury and infections (9). Several clinical studies reported that inflammatory mediator responses, mainly IL-6 and CRP were attenuated after laparoscopic-assisted colectomy (10). This phenomenon was also examined in VATS compared to open thoracotomy: clinical studies focused on cytokine, CRP responses and demonstrated lower postoperative levels of CRP, IL-6 and IL-8 after VATS lobectomy (11-13). However, TNF- $\alpha$ and IL-1 $\beta$ levels, that are regulated by IL-6, were not altered after VATS lobectomy, as compared to open thoracotomy (11). IL-6 can promote tumour proliferation through the activation of insulin-like growth factor (IGF)-1 and the inhibition of insulin-like growth factor binding protein (IGFBP)-3 (14). Recently, IGF-1 was recognized to play a role in facilitating tumour growth and in inhibiting tumour cell apoptosis (15). IGF-1 is kept to be a key regulator in both small cell and NSCLC, so preliminary studies suggested that anti-IGF-1R monoclonal antibody can be a future efficient treatment option (16). IGFBP-3 can bind to IGF-1, influence DNA synthesis and induce the apoptosis of tumour cells, acting as an important inhibitory factor in tumorigenesis $(17,18)$. Plasma levels of IGFBP-3 decreased after laparotomy but not laparoscopic colectomy. Moreover, IL-6 elevated levels were associated with reduced circulating IGFBP-3 in patients underwent laparotomy (19). Similarly, on postoperative day 3, early stage NSCLC patients after VATS lung resection showed significantly higher IGFBP-3 levels without clinical benefits, compared to open thoracotomy (20). Another study reported that IGFBP-3 levels were dramatically lower in case of VATS, compared to thoracotomy (21). Clearly, strong conclusions cannot be drawn and further studies needed to confirm the role of IGFBP-3 in VATS operated patients.

Furthermore, the release of matrix metalloproteinase (MMP)-9 from mononuclear cells can be induced by surgical interventions. MMP-9 provokes tumour invasion through the degradation of collagens in the basal membranes and inhibits IGFBP-3, resulting tumour 


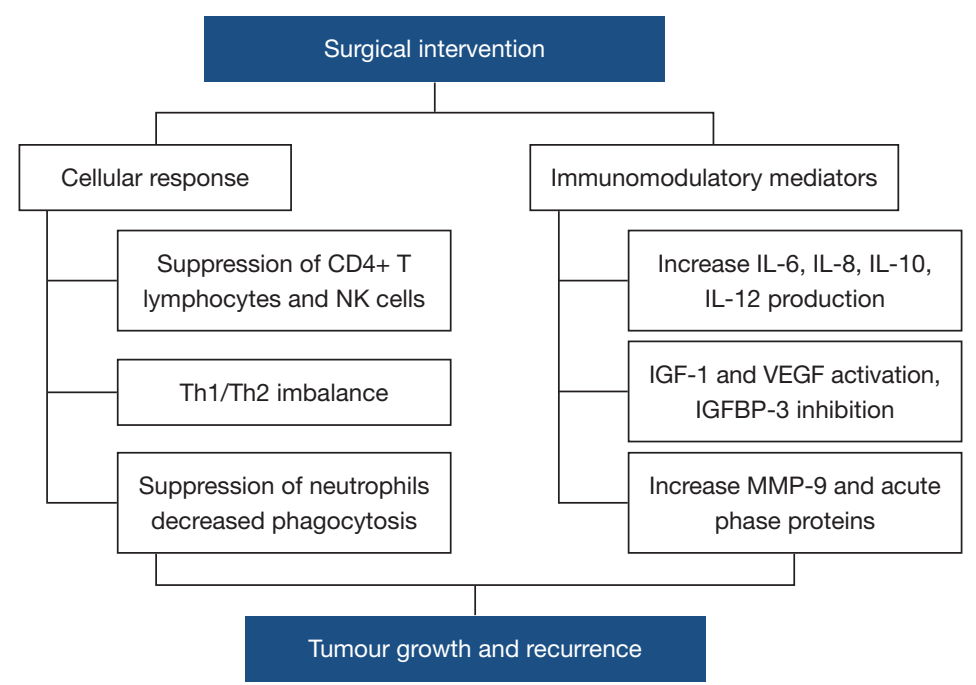

Figure 1 An overview of immune factors influenced by thoracic surgery. NK, natural killer; IL, interleukin; IGF-1, insulin-like growth factor 1; VEGF, vascular endothelial growth factors; IGFBP-3, insulin-like growth factor binding protein 3; MMP-9, matrix metalloproteinase 9.

invasion and forming metastasis (22). VATS is reported to reduce the MMP-9 levels from postoperative day 1, compared to thoracotomy (20).

IL-10, an anti-inflammatory T helper 2 (Th2) cytokine that can reduce cellular immunity and promote the escape of tumour cells via suppressing cell-mediated cytotoxicity; was also reduced after VATS lobectomy (11). Jones et al. enrolled NSCLC patients to detect the possible changes in blood and bronchoalveolar lavage (BAL) fluid before and after VATS and thoracotomy. The authors suggested that VATS caused lower pro-inflammatory cytokine levels in the blood, but interestingly, in BAL fluid significant differences were not detected, compared to thoracotomy. Lipopolysaccharide (LPS)-stimulated monocytes derived from VATS patients produced lower levels of IL-10 at 6 hours postoperatively (23). These findings should gain importance in clinical practice, as IL-10 can inhibit natural killer (NK) cells that are responsible for tumour cell killing. Consequently, the reduced IL-10 release can contribute to avoid the spreading of tumour cells and to their escape from the cellular immunity.

Besides, cellular responses did not remain unaltered in surgical procedures: $\mathrm{Wu}$ et al. reported that after laparoscopic colectomy the leukocyte cell counts and their HLA-DR expression were less affected after the surgery, compared to open colectomy (24). Similarly, VATS has been associated with less suppressed cell mediated immunity and had less influence on the circulating $\mathrm{CD} 4^{+}$ $\mathrm{T}$ cells and on NK cells postoperatively; moreover, the levels of lymphocytes normalised earlier, as well. The oxidative process and cytotoxic activity of lymphocytes were less suppressed in case of VATS, indicating that VATS has less detrimental effect on lymphocyte signalling and their functions (25). Thoracotomy can also reduce the number of total $\mathrm{T}$ cell count, $\mathrm{CD}^{+}$and $\mathrm{CD}^{+} \mathrm{T}$ cells on postoperative day 1 and $\mathrm{NK}$ cells on postoperative day 7 , that were not observed in NSCLC patients after VATS (26). Neutrophil granulocytes showed less reduction, compared to thoracotomy and their phagocyte activity and the production of reactive oxygen species (ROS) are less altered after VATS (12).

Although VATS can preserve better the cellular functions and cytokine production than thoracotomy, long-term clinical benefits are awaiting for confirmation. A prospective study showed that 5- and 10-year survival of patients underwent VATS lung resection did not differ from those who underwent open thoracotomy (27). West et al. concluded that long-term data supporting VATS to be superior to thoracotomy regarding survival, hospital stay or tumour recurrence are still controversial (28).

It is of interest that the majority of studies in connection with immune mechanisms were conducted with a relatively small sample size and samples were taken within 5 days postoperatively, thus, there is no evidence yet that these changes can enhance patients' future survival and improved tumour immunosurveillance. The main immune factors that can affect future tumour growth after thoracic surgery are summarized on Figure 1. 


\section{Mechanical one-lung ventilation as a potential predisposing factor to immunological imbalance}

Besides surgical manipulation and invasiveness, mOLV has been widely recognised to increase the risk of postoperative pulmonary complications and acute lung injury (ALI) (29,30). During mOLV both the ventilated and collapsed lung show a spectrum of pathophysiologic mechanism that interfere with the integrity of pulmonary endothelial glycocalyx that is responsible for maintaining oncotic pressure and modulate cell-cell interactions (31). Subsequently, the mitigation of the glycocalyx triggers a wide range of immunological detrimental effects leading to ALI and higher postoperative mortality. mOLV can induce the release of pro-inflammatory mediators such as TNF- $\alpha$, IL- 6 , IL- 8 , IL- $1 \beta$ and promote the activation and recruitment of neutrophils and pulmonary macrophages. As a result, bacteria, bacteria-derived LPS and cytokines can invade the host circulation leading to pulmonary oedema, capillary leak, acute respiratory distress syndrome (ARDS) and even to multi-organ dysfunction (8).

The initiation of lung protective ventilation with low tidal volumes $(\mathrm{Vt})$ and positive end-expiratory pressure (PEEP) could hamper the consequences of mOLV, however, to some extent lung injury is unavoidable. Clearly, the ventilated lung can suffer from overdistension at high volumes and atelectasis at low volumes, both could accentuate the already existing lung injury and decreased lung compliance. Several studies were conducted to determine the harmful outcomes of mOLV in case of conventional and lung protective ventilation. Focusing on the release of cytokines, Schilling et al. demonstrated that patients undergoing major pulmonary resections and mechanical ventilation at $5 \mathrm{~mL} / \mathrm{kg} \mathrm{Vt}$ could gain favourable cytokine responses, compared to patients receiving $10 \mathrm{~mL} / \mathrm{kg}$ Vt during thoracic surgery. Their main findings included decreased TNF- $\alpha$ concentrations and decreased soluble intercellular adhesion molecule-1 (sICAM-1) levels in BAL fluid, emphasizing that the reduction of $\mathrm{Vt}$ may contribute to beneficial immune responses (32). Similarly, in case of oesophagectomy Shen et al. certified that BAL fluid contains significantly lower concentrations of TNF- $\alpha$, IL-1 $\beta$, IL- 6 and IL- 8 at $18 \mathrm{~h}$ postoperatively in patients ventilated at low $\mathrm{Vt}(5 \mathrm{~mL} / \mathrm{kg})(33)$. Besides $\mathrm{Vt}$, protective ventilation using continuous positive airway pressure (CPAP) during minimally invasive oesophagectomy resulted in an attenuated IL- $1 \alpha$, IL- $1 \beta$, IL-6, IL-8, IL-10 and macrophage inflammatory protein $1 \alpha$ (MIP- $1 \alpha$ levels in the BAL fluids of the ventilated and collapsed lung (34). Indeed, Breunig et al. investigated the cytokine responses in BAL, blood and pleural fluids of the collapsed, operated and the ventilated, non-operated lungs in patients undergoing pulmonary resections. They reported that the levels of IL-6 were significantly higher in both lungs, but IL-1RA was elevated only in the operated lungs. Similar but less pronounced patterns were observed in the blood and pleural fluids, except the chemokine GRO- $\alpha$, a chemoattractant for neutrophils, showed significant increase in pleural fluid and blood a day after surgery, indicating a late inflammatory response in both lungs (35).

To address the question whether Vt or higher airway pressure may contribute to lung injury, several animal and clinical studies were conducted. One of them reported that lung overdistension with high volumes at the end of inspiration phase triggered lung injury. Although, decreased lung compliance should be taken into account in humans before applying mOLV (36,37). A further animal study suggested that alveolar recruitment manoeuvers are not the most harmful effect itself and did not induce proinflammatory cytokine production in one-lung ventilated pigs (38). Indeed, a rat model also demonstrated that not cyclic opening and closing of the alveoli is associated with elevated pro-inflammatory cytokine concentrations in BAL fluid, rather lung overdistension at high volumes resulted in an accelerated cytokine production (39).

Thus, mOLV could induce a cytokine release, the recruitment of inflammatory cells and activation of neutrophils, promoting cell death and deteriorating the integrity of the airway epithelium, resulting in acute distress syndrome and increased mortality in these patients (40).

Nevertheless, this kind of biotrauma is also detected in the collapsed lung during mOLV. Strikingly, a 3-hour duration of lung collapse did not result in increased cytokine release in a rat model (39), in contrast, in an ex vivo rabbit model after a short-term collapse, lung expansion from the total atelectasis induces TNF- $\alpha$ and IL-1 $\beta$ mRNA expression in the collapsed lung and triggered pulmonary oedema (41). Another study by Leite $e t a l$. demonstrated in an in vivo rat model that after 1- or 3-hour duration of mOLV followed by 1-hour lung re-expansion increased the levels of TNF- $\alpha$, IL-1 $\beta$, IL-6 in BAL fluid, induced pulmonary myeloperoxidase (MPO) activity, protein extravasation, neutrophil recruitment and elevated IL-6 and IL-10 concentrations in serum, suggesting that in the collapsed lung re-expansion could exhibit an increase in pro-inflammatory mediators, thus, contribute to further deterioration of the alveolar-capillary membrane (42). 
The main prospective laboratory animal and clinical studies demonstrating the immune effects of ventilation are summarized in Table 1.

Furthermore, the collapsed lung suffers from ischaemia- reperfusion effect that accelerated the production of proinflammatory cytokines and vascular permeability (49). The collapse is also associated with increased production of reactive oxygen species that is specific to mOLV compared

Table 1 Prospective human and animal studies on immune responses attributed to mechanical ventilation, general anaesthesia and non-intubated VATS

\begin{tabular}{|c|c|c|c|}
\hline Reference & Study design & Procedure & Main findings \\
\hline $\begin{array}{l}\text { Schilling } \\
\text { et al. (32) }\end{array}$ & $\mathrm{RCT}$ & $\begin{array}{l}\text { Thoracotomy: } 16 \text { patients received Vt } 10 \mathrm{~mL} / \mathrm{kg}, 16 \\
\text { patients received Vt } 5 \mathrm{~mL} / \mathrm{kg}\end{array}$ & $\begin{array}{l}\text { The reduction of Vt decreased the levels of } \\
\text { TNF- } \alpha \text { and SICAM- } 1 \text { in BAL fluid }\end{array}$ \\
\hline $\begin{array}{l}\text { Shen } \\
\text { et al. (33) }\end{array}$ & $\mathrm{RCT}$ & $\begin{array}{l}\text { Minimally invasive oesophagectomy ( } \mathrm{n}=101 \\
\text { patients); preserved ventilation group ( } \mathrm{PV}, \mathrm{n}=53 \\
\text { patients, Vt } 5 \mathrm{~mL} / \mathrm{kg}) \text {, conventional controlled } \\
\text { ventilation group }(\mathrm{CV}, \mathrm{n}=48 \text { patients, Vt } 8 \mathrm{~mL} / \mathrm{kg} \text { ) }\end{array}$ & $\begin{array}{l}\text { PV patients exhibited lower concentrations } \\
\text { of TNF- } \alpha \text {, IL-1 } 1 \beta \text {, IL- } 6 \text { and IL- } 8 \text { in BALF at } \\
18 \text { h postoperatively; PV patients showed } \\
\text { better clinical outcomes: less pulmonary } \\
\text { complications, reintubation and pleural effusion }\end{array}$ \\
\hline $\begin{array}{l}\text { Verhage } \\
\text { et al. (34) }\end{array}$ & $\mathrm{RCT}$ & $\begin{array}{l}\text { Minimally invasive oesophagectomy for cancer } \\
(\mathrm{n}=30 \text { patients), } 15 \text { patients received CPAP }(5 \mathrm{~cm} \\
\left.\mathrm{H}_{2} \mathrm{O}\right) \text { during mOLV }\end{array}$ & $\begin{array}{l}\text { CPAP group had decreased IL- } 1 \alpha \text {, IL- } 1 \beta \text {, IL- } 6 \text {, } \\
\text { IL- } 8 \text {, IL- } 10 \text { and MIP- } 1 \alpha \text { both in the BALF of the } \\
\text { ventilated and collapsed lung }\end{array}$ \\
\hline $\begin{array}{l}\text { Schilling } \\
\text { et al. (38) }\end{array}$ & $\begin{array}{l}\text { Prospective, } \\
\text { randomised, } \\
\text { controlled } \\
\text { laboratory study } \\
\text { (porcine model) }\end{array}$ & $\begin{array}{l}\text { Spontaneous breathing }(n=4) \text {, two-lung ventilation } \\
(T L V, n=6) \text {, mOLV with propofol }(6 \mathrm{mg} / \mathrm{kg} / \mathrm{h}, \mathrm{n}=6) \text { or } \\
\text { desflurane anaesthesia ( } 1 \mathrm{MAC}, \mathrm{n}=6) \text {. }\end{array}$ & $\begin{array}{l}\text { Alveolar recruitment manoeuvres and TLV } \\
\text { did not result in pro-inflammatory responses. } \\
\text { mOLV significantly enhanced TNF- } \alpha \text { release } \\
\text { in propofol anaesthetised pigs. IL- } 8 \text { mRNA } \\
\text { expression was enhanced by OLV, but not } \\
\text { anaesthetic drugs. }\end{array}$ \\
\hline $\begin{array}{l}\text { Chu } \\
\text { et al. (39) }\end{array}$ & $\begin{array}{l}\text { Prospective, } \\
\text { randomised, } \\
\text { controlled } \\
\text { laboratory study (rat } \\
\text { model) }\end{array}$ & $\begin{array}{l}\text { Ex vivo rat model }(n=88) \text {, study I: ventilation at low } \\
\text { volumes (ZEEP, PEEP and atelectasis group), study } \\
\text { II: ventilation at high volumes }\end{array}$ & $\begin{array}{l}\text { In study I PEEP was not associated with higher } \\
\text { pro-inflammatory cytokine levels in BALF. } \\
\text { ZEEP group showed elevated MIP-2. At high } \\
\text { volumes, TNF- } \alpha \text { and IL- } 6 \text { cytokine production } \\
\text { were associated with overdistension, but not } \\
\text { with cyclic opening and closing of the alveoli }\end{array}$ \\
\hline $\begin{array}{l}\text { Leite } \\
\text { et al. (42) }\end{array}$ & $\begin{array}{l}\text { Prospective, } \\
\text { randomised, } \\
\text { controlled } \\
\text { laboratory study (rat } \\
\text { model) }\end{array}$ & $\begin{array}{l}\mathrm{n}=30,1 \text { - or } 3 \text {-hour OLV followed or not by } 1 \text {-hour } \\
\text { lung re-expansion, control: not ventilated }\end{array}$ & $\begin{array}{l}\text { Rats underwent } 1 \text { - or } 3 \text {-hour OLV followed } \\
\text { by lung re-expansion showed neutrophil } \\
\text { recruitment, higher MPO activity, increased } \\
\text { levels of IL-6, IL-1 } \beta \text {, and TNF- } \alpha \text { in BALF and } \\
\text { increased levels of IL- } 6 \text { and IL-10 in serum }\end{array}$ \\
\hline
\end{tabular}

Table 1 (continued) 
Table 1 (continued)

\begin{tabular}{|c|c|c|c|}
\hline Reference & Study design & Procedure & Main findings \\
\hline $\begin{array}{l}\text { Schilling } \\
\text { et al. (43) }\end{array}$ & $\mathrm{RCT}$ & $\begin{array}{l}\text { Patients underwent open thoracic surgery were } \\
\text { randomised to receive propofol } 4 \mathrm{mg} / \mathrm{kg} / \mathrm{h}(\mathrm{n}=15) \text { or } \\
1 \mathrm{MAC} \text { desflurane }(n=15) \text { during } \mathrm{mOLV}\end{array}$ & $\begin{array}{l}\text { Propofol anaesthesia resulted in alveolar } \\
\text { granulocyte recruitment and increased the } \\
\text { levels of TNF- } \alpha, \text { sICAM- } 1 \text { in BALF }\end{array}$ \\
\hline $\begin{array}{l}\text { Schilling } \\
\text { et al. (44) }\end{array}$ & $\mathrm{RCT}$ & $\begin{array}{l}63 \text { patients underwent thoracotomy were assigned } \\
\text { to receive anaesthesia with } 4 \mathrm{mg} / \mathrm{kg} / \mathrm{h} \text { propofol } \\
(\mathrm{n}=21), 1 \text { MAC desflurane }(n=21) \text {, or } 1 \text { MAC } \\
\text { sevoflurane }(n=21)\end{array}$ & $\begin{array}{l}\text { Pro-inflammatory cytokines increased in the } \\
\text { ventilated lung after OLV. Propofol evoked } \\
\text { significantly the production of TNF- } \alpha \text { and IL-8 }\end{array}$ \\
\hline $\begin{array}{l}\text { De Conno } \\
\text { et al. }(45)\end{array}$ & $\mathrm{RCT}$ & $\begin{array}{l}54 \text { patients underwent thoracotomy were } \\
\text { randomised to receive intravenously applied } \\
\text { propofol or the volatile anaesthetic sevoflurane }\end{array}$ & $\begin{array}{l}\text { Sevoflurane reduced the levels of TNF- } \alpha \text {, IL- } 1 \beta \text {, } \\
\text { IL- } 6 \text {, IL- } 8 \text { and MCP- } 1 \text { and was associated with } \\
\text { less postoperative complications }\end{array}$ \\
\hline \multicolumn{4}{|c|}{ Cell and cytokine responses in non-intubated VATS } \\
\hline $\begin{array}{l}\text { Mineo } \\
\text { et al. (47) }\end{array}$ & $\mathrm{RCT}$ & $\begin{array}{l}55 \text { patients underwent intubated or non-intubated } \\
\text { VATS metastasectomy were enrolled }\end{array}$ & $\begin{array}{l}\text { Non-intubated patients showed lesser } \\
\text { reduction of NK cells, and attenuated IL-6 } \\
\text { production postoperatively }\end{array}$ \\
\hline $\begin{array}{l}\text { Jeon } \\
\text { et al. (48) }\end{array}$ & $\mathrm{RCT}$ & $\begin{array}{l}40 \text { stage I NSCLC patients underwent non- } \\
\text { intubated or intubated VATS were assigned to } \\
\text { evaluate early postoperative changes in blood } \\
\text { samples }\end{array}$ & $\begin{array}{l}\text { The levels of IL- } 6 \text { and TNF- } \alpha \text { were significantly } \\
\text { lower in the non-intubated group } 1 \text { and } 24 \mathrm{~h} \\
\text { postoperatively. IL- } 4 \text { and IL- } 10 \text { were not altered }\end{array}$ \\
\hline
\end{tabular}

BALF, bronchoalveolar lavage fluid; CPAP, continuous positive airway pressure; MAC, minimum alveolar concentration; MCP-1, monocyte chemoattractant protein 1; OLV, one-lung ventilation; PEEP, positive end expiratory pressure; RCT, randomised controlled trial; sICAM-1, soluble intercellular adhesion molecule-1; TNF- $\alpha$, tumour necrosis factor- $\alpha$; VATS, video-assisted thoracic surgery; ZEEP, zero end expiratory pressure.

to 2-lung ventilated patients. This finding has a prominent relevance, as patients with cancer have less antioxidant capacity, therefore, mOLV may influence negatively the mortality of these patients (50). Taken together, previous studies established that during mOLV both the ventilated and collapsed lung showed the alterations of proinflammatory cytokine production, neutrophil and reactive oxygen species activity, resulting in an increased leak of the capillary membrane, pulmonary oedema, harm to the alveoli and ALI. Thus, it raised the necessity of the non-intubated thoracic surgeries to avoid the conceivable immunological detrimental effects.

\section{The effects of anaesthesia on immune responses during thoracic surgery}

Since Riddle et al. reported that general anaesthesia triggered a decrease in lymphocyte cell response to a polyclonal mitogen, phytohaemagglutinin, an increased number of studies were conducted to investigate the immunomodulatory effects of anaesthetic agents on immune response during and after surgery (51). Further studies described a decreased production of IL-2 by peripheral mononuclear cells and mitigated hydrogen peroxide production by monocytes after anaesthesia $(52,53)$. The immunosuppressive effects of anaesthesia have been also thoroughly observed on T-lymphocytes and NK cells $(54,55)$ that has a pronounced role in antitumor activity, cytokine production and cell killing. Exposure to morphine, halothane, enflurane or nitrous oxide was in conjunction with decreased NK cell cytotoxicity $(56,57)$. Indeed, Markovic et al. found that preoperative administration of interferon (IFN)- $\alpha / \beta$ and neoadjuvant chemotherapy before anaesthesia with halothane or isoflurane prevented the 
suppression of $\mathrm{NK}$ cell activity, that had a protective role in forming lung metastases after tumour resection in a murine model (58-60). After administering isoflurane and nitrous oxide during general anaesthesia, Kutza et al. evaluated the IFN- $\alpha$-stimulated NK cytotoxicity in humans. The authors found that basal NK cytotoxicity was decreased during and 24 hours after surgery, however, IFN- $\alpha$ reversed the suppression of NK cells associated with anaesthesia (61). Moreover, Schilling et al. revealed that intravenously applied propofol evoked alveolar granulocyte recruitment and increased the levels of TNF- $\alpha$, sICAM-1 in BALF, compared with patients receiving desflurane (43). Similarly, desflurane and sevoflurane attenuated the production of TNF- $\alpha$, IL- $1 \beta$ and IL- 8 in the ventilated lungs (44). De Conno et al. also reported favourable inflammatory changes, as applying sevoflurane reduced the levels of TNF- $\alpha$, IL-1 $\beta$, IL-6, IL-8 and MCP-1 and resulted in better clinical outcomes (45). Since then, prospective trials were introduced to test medications that may potentially prevent the harmful effects of general anaesthesia. One of them administered preoperatively nebulised budesonide and observed a significant reduction of ventilatory pressures and increased lung compliance during lung re-expansion in patients undergoing lobectomy. Moreover, budesonide pretreatment was associated with reduced levels of $\mathrm{TNF}-\alpha$, IL-1 $\beta$, IL-6 and IL-8 in BAL fluid 30 min post-OLV (62). A neutrophil elastase inhibitor, sivelestat improved lung injury score, lung function and reduced mortality rates after lung lobectomy with mOLV and general anaesthesia (63).

The main prospective studies reporting the immune effects of anaesthesia are summarized in Table 1.

Collectively, data suggest the concept of switching general anaesthesia to local and regional anaesthesia techniques that have enabled thoracic surgery to perform a more feasible, safety approach without intubation and administering disadvantageous anaesthetic agents with regard to patients' potential risk factors $(64,65)$.

\section{The immune and oncological effects of non- intubated thoracic surgery}

Non-intubated thoracic surgical procedures are widely used to perform minor and major thoracic surgeries, and is a feasible technique to perform pleural and lung biopsies, metastasectomies, anatomical lung resections and surgeries to pneumothorax $(66,67)$. The main principle is to create iatrogenic pneumothorax, thus, the operator has enough space to implement the surgery and to avoid the use of double-lumen endotracheal tube. Non-intubated VATS is a preferred technique in patients with reduced lung function to avoid prolonged mechanical ventilation. It is well-established that during non-intubated thoracic surgery loco-regional anaesthesia is used as an alternative instead of general anaesthesia, thus, provide a faster recovery. As spontaneous breathing is maintained through the nonintubated thoracic procedures, this type of surgery can be doable in lung cancer patients to avoid the detrimental effects of surgery on immune responses (66).

Consequently, in recent years non-intubated procedures became in the focus of studies investigating postoperative outcomes and their favourable impacts on patients' immune responses. Intubated techniques hold adverse effects such as facilitating tumour recurrence that derives from the modified activity of $\mathrm{NK}$ cells and cytokine production. In contrast, non-intubated surgeries are hypothesised to prevent this impact and had less influence on proinflammatory immune responses. To our knowledge, there are few prospective studies that concentrated on inflammatory impact of non-intubated surgeries. Mineo and Ambrogi compared the total lymphocyte, NK cell counts, 30-day mortality, hospital stay and postoperative complications in intubated and non-intubated patients underwent VATS operations. They demonstrated that total lymphocytes and NK cells showed a significantly less reduction in the non-intubated group, along with significantly lower morbidity rates and hospital stay (46). Moreover, it has been published that patients underwent non-intubated VATS metastasectomy showed a lesser drop in NK cell count on day 7 postoperatively, and a decreased production of IL-6 on postoperative day 1, 7 and even 14, compared to the intubated VATS group. However, IL10 production and mortality rates reflected no significant change between the groups. To add, hospital stay duration and healthcare-related costs were reduced in case of nonintubated VATS technique (47). A further randomised controlled study investigated early postoperative changes in stage I NSCLC patients underwent VATS resection. They investigated TNF- $\alpha$, IL-1 $\beta$, IL-6, IL-4 and IL-10 cytokine changes in patients' sera before anaesthesia, 1 and $24 \mathrm{~h}$ postoperatively. IL-6 and TNF- $\alpha$ were significantly lower at 1 and $24 \mathrm{~h}$ postoperatively in the non-intubated group, compared with patients after mOLV, however, other cytokines did not differ between the patients (48). Nevertheless, this recent study concentrated on patients with stage I lung cancer and lobectomy, although, it was the first study initiated to detect comparable cytokine changes 
in lung cancer patients in a trial. Their findings expressed the demand to define cytokine amendments in major pulmonary resection in different stages of lung cancer.

Regarding oncological outcomes, it is well-established that VATS is superior over thoracotomy, being associated with lower morbidity, postoperative complications and facilitating the delivery of adjuvant chemotherapies $(4,7,68)$. Moreover, after thoracoscopic procedures improved tolerance to chemotherapy was observed with fewer delay, dose reductions and less severe side-effects independently of the stage of NSCLC patients and the type of adjuvant agents (69-71). In contrast, there are little data about the clinical and oncological benefits of nonintubated lobectomies. A retrospective study by Furák et al. reported a significantly higher compliance to adjuvant chemotherapy in non-intubated patients compared to intubated individuals, as $92 \%$ of non-intubated patients were capable of completing the planned chemotherapy protocol, in contrary to $72 \%$ of intubated patients. Grade 1 or 2 toxicity were observed more frequent among intubated patients and the incidence of grade 4 neutropenia was lower with significance among non-intubated patients (72). These results indicated that non-intubated NSCLC patients could benefit from this technique, theoretically, this impact could derive from less influenced immune responses. Although, their study is limited by the retrospective design, the results suggested the need of conducting comparable prospective research including immune markers and oncological outcomes that would have answer the question whether non-intubated procedure is associated with better clinical performance because of the favourable immune effects. Regarding clinical benefits, a meta-analysis revealed that non-intubated VATS could shorten hospitalization stay and chest-tube duration, compared with intubated VATS (73). A further study also demonstrated that non-intubated patients had better overall drainage volume and recovery time (74). The main prospective studies reporting the immune effects of NITS are summarized in Table 1.

\section{Conclusions}

Collectively, retrospective and prospective studies advanced some concepts suggesting that intubated VATS can be associated with less decreased circulating T cell and NK cell numbers, phagocyte and oxidative activity and with to less extent elevated levels of cytokines, compared to thoracotomy. Furthermore, mechanical ventilation and general anaesthetic agents may contribute to an elevated pro-inflammatory cytokine production and disturbed cell functions. Thus, NITS could be an alternative option for NSCLC patients to minimize immunological alterations. NITS seemed to induce preserved immune functions along with improved clinical outcomes, although, previous studies were limited by small sample size and their retrospective nature. Notably, prospective, multi-center studies should be proposed to assess feasibility and to establish the correlation between the production of pro-inflammatory cytokines, the altered immune cell responses and clinical benefits in NSCLC patients.

\section{Acknowledgments}

Funding: None.

\section{Footnote}

Provenance and Peer Review: This article was commissioned by the Guest Editor (József Furák) for the series "Spontaneous Ventilation Thoracic Surgery" published in AME Surgical fournal. The article has undergone external peer review.

Reporting Checklist: The authors have completed the Narrative Review reporting checklist. Available at https:// asj.amegroups.com/article/view/10.21037/asj-21-64/rc

Peer Review File: Available at https://asj.amegroups.com/ article/view/10.21037/asj-21-64/prf

Conflicts of Interest: All authors have completed the ICMJE uniform disclosure form (available at https://asj. amegroups.com/article/view/10.21037/asj-21-64/coif). The series "Spontaneous Ventilation Thoracic Surgery" was commissioned by the editorial office without any funding or sponsorship. The authors have no other conflicts of interest to declare.

Ethical Statement: The authors are accountable for all aspects of the work in ensuring that questions related to the accuracy or integrity of any part of the work are appropriately investigated and resolved.

Open Access Statement: This is an Open Access article distributed in accordance with the Creative Commons Attribution-NonCommercial-NoDerivs 4.0 International License (CC BY-NC-ND 4.0), which permits the noncommercial replication and distribution of the article with 
the strict proviso that no changes or edits are made and the original work is properly cited (including links to both the formal publication through the relevant DOI and the license). See: https://creativecommons.org/licenses/by-nc-nd/4.0/.

\section{References}

1. Dąbrowska AM, Słotwiński R. The immune response to surgery and infection. Cent Eur J Immunol 2014;39:532-7.

2. Marik PE, Flemmer M. The immune response to surgery and trauma: Implications for treatment. J Trauma Acute Care Surg 2012;73:801-8.

3. Eppensteiner J, Davis RP, Barbas AS, et al. Immunothrombotic Activity of Damage-Associated Molecular Patterns and Extracellular Vesicles in Secondary Organ Failure Induced by Trauma and Sterile Insults. Front Immunol 2018;9:190.

4. Villamizar NR, Darrabie MD, Burfeind WR, et al. Thoracoscopic lobectomy is associated with lower morbidity compared with thoracotomy. J Thorac Cardiovasc Surg 2009;138:419-25.

5. Whitson BA, D'Cunha J, Andrade RS, et al. Thoracoscopic versus thoracotomy approaches to lobectomy: differential impairment of cellular immunity. Ann Thorac Surg 2008;86:1735-44.

6. Jiang G, Yang F, Li X, et al. Video-assisted thoracoscopic surgery is more favorable than thoracotomy for administration of adjuvant chemotherapy after lobectomy for non-small cell lung cancer. World J Surg Oncol 2011;9:170.

7. Nicastri DG, Wisnivesky JP, Litle VR, et al. Thoracoscopic lobectomy: report on safety, discharge independence, pain, and chemotherapy tolerance. J Thorac Cardiovasc Surg 2008; $135: 642-7$.

8. Lohser J, Slinger P. Lung Injury After One-Lung Ventilation: A Review of the Pathophysiologic Mechanisms Affecting the Ventilated and the Collapsed Lung. Anesth Analg 2015;121:302-18.

9. Schietroma M, Carlei F, Mownah A, et al. Changes in the blood coagulation, fibrinolysis, and cytokine profile during laparoscopic and open cholecystectomy. Surg Endosc 2004;18:1090-6.

10. Delgado S, Lacy AM, Filella X, et al. Acute phase response in laparoscopic and open colectomy in colon cancer: randomized study. Dis Colon Rectum 2001;44:638-46.

11. Yim AP, Wan S, Lee TW, et al. VATS lobectomy reduces cytokine responses compared with conventional surgery. Ann Thorac Surg 2000;70:243-7.

12. Craig SR, Leaver HA, Yap PL, et al. Acute phase responses following minimal access and conventional thoracic surgery. Eur J Cardiothorac Surg 2001;20:455-63.

13. Nagahiro I, Andou A, Aoe M, et al. Pulmonary function, postoperative pain, and serum cytokine level after lobectomy: a comparison of VATS and conventional procedure. Ann Thorac Surg 2001;72:362-5.

14. Chang KT, Tsai CM, Chiou YC, et al. IL-6 induces neuroendocrine dedifferentiation and cell proliferation in non-small cell lung cancer cells. Am J Physiol Lung Cell Mol Physiol 2005;289:L446-53.

15. Wu Y, Yakar S, Zhao L, et al. Circulating insulin-like growth factor-I levels regulate colon cancer growth and metastasis. Cancer Res 2002;62:1030-5.

16. Dziadziuszko R, Camidge DR, Hirsch FR. The insulinlike growth factor pathway in lung cancer. J Thorac Oncol 2008;3:815-8.

17. Chang YS, Kong G, Sun S, et al. Clinical significance of insulin-like growth factor-binding protein-3 expression in stage I non-small cell lung cancer. Clin Cancer Res 2002;8:3796-802.

18. Kirman I, Poltoratskaia N, Sylla P, et al. Insulin-like growth factor-binding protein 3 inhibits growth of experimental colocarcinoma. Surgery 2004;136:205-9.

19. Kirman I, Poltaratskaia N, Cekic V, et al. Depletion of circulating insulin-like growth factor binding protein 3 after open surgery is associated with high interleukin-6 levels. Dis Colon Rectum 2004;47:911-7; discussion 917-8.

20. Ng CS, Wan S, Hui CW, et al. Video-assisted thoracic surgery lobectomy for lung cancer is associated with less immunochemokine disturbances than thoracotomy. Eur J Cardiothorac Surg 2007;31:83-7.

21. Zhang LB, Wang B, Wang XY, et al. Influence of videoassisted thoracoscopic lobectomy on immunological functions in non-small cell lung cancer patients. Med Oncol 2015;32:201.

22. Belizon A, Kirman I, Balik E, et al. Major surgical trauma induces proteolysis of insulin-like growth factor binding protein-3 in transgenic mice and is associated with a rapid increase in circulating levels of matrix metalloproteinase-9. Surg Endosc 2007;21:653-8.

23. Jones RO, Anderson NH, Murchison JT, et al. Innate immune responses after resection for lung cancer via video-assisted thoracoscopic surgery and thoracotomy. Innovations (Phila) 2014;9:93-103; discussion 103.

24. Wu FP, Sietses C, von Blomberg BM, et al. Systemic and peritoneal inflammatory response after laparoscopic or conventional colon resection in cancer patients: a prospective, randomized trial. Dis Colon Rectum 2003;46:147-55. 
25. Leaver HA, Craig SR, Yap PL, et al. Lymphocyte responses following open and minimally invasive thoracic surgery. Eur J Clin Invest 2000;30:230-8.

26. Ng CS, Lee TW, Wan S, et al. Thoracotomy is associated with significantly more profound suppression in lymphocytes and natural killer cells than video-assisted thoracic surgery following major lung resections for cancer. J Invest Surg 2005;18:81-8.

27. Thomas P, Doddoli C, Yena S, et al. VATS is an adequate oncological operation for stage I non-small cell lung cancer. Eur J Cardiothorac Surg 2002;21:1094-9.

28. West D, Rashid S, Dunning J. Does video-assisted thoracoscopic lobectomy produce equal cancer clearance compared to open lobectomy for non-small cell carcinoma of the lung? Interact Cardiovasc Thorac Surg 2007;6:110-6.

29. Lohser J. Evidence-based management of one-lung ventilation. Anesthesiol Clin 2008;26:241-72, v.

30. Licker MJ, Widikker I, Robert J, et al. Operative mortality and respiratory complications after lung resection for cancer: impact of chronic obstructive pulmonary disease and time trends. Ann Thorac Surg 2006;81:1830-7.

31. Collins SR, Blank RS, Deatherage LS, et al. Special article: the endothelial glycocalyx: emerging concepts in pulmonary edema and acute lung injury. Anesth Analg 2013;117:664-74.

32. Schilling T, Kozian A, Huth C, et al. The pulmonary immune effects of mechanical ventilation in patients undergoing thoracic surgery. Anesth Analg 2005;101:957-65.

33. Shen $\mathrm{Y}$, Zhong $\mathrm{M}, \mathrm{Wu} \mathrm{W}$, et al. The impact of tidal volume on pulmonary complications following minimally invasive esophagectomy: a randomized and controlled study. J Thorac Cardiovasc Surg 2013;146:1267-73; discussion 1273-4.

34. Verhage RJ, Boone J, Rijkers GT, et al. Reduced local immune response with continuous positive airway pressure during one-lung ventilation for oesophagectomy. Br J Anaesth 2014;112:920-8.

35. Breunig A, Gambazzi F, Beck-Schimmer B, et al. Cytokine \& chemokine response in the lungs, pleural fluid and serum in thoracic surgery using one-lung ventilation. J Inflamm (Lond) 2011;8:32.

36. Slinger PD, Johnston MR. Preoperative assessment for pulmonary resection. Anesthesiol Clin North Am 2001;19:411-33.

37. Ducros L, Moutafis M, Castelain MH, et al. Pulmonary air trapping during two-lung and one-lung ventilation. J Cardiothorac Vasc Anesth 1999;13:35-9.

38. Schilling T, Kretzschmar M, Hachenberg T, et al. The immune response to one-lung-ventilation is not affected by repeated alveolar recruitment manoeuvres in pigs. Minerva Anestesiol 2013;79:590-603.

39. Chu EK, Whitehead T, Slutsky AS. Effects of cyclic opening and closing at low- and high-volume ventilation on bronchoalveolar lavage cytokines. Crit Care Med 2004;32:168-74.

40. Tang SS, Redmond K, Griffiths M, et al. The mortality from acute respiratory distress syndrome after pulmonary resection is reducing: a 10-year single institutional experience. Eur J Cardiothorac Surg 2008;34:898-902.

41. Funakoshi T, Ishibe Y, Okazaki N, et al. Effect of reexpansion after short-period lung collapse on pulmonary capillary permeability and pro-inflammatory cytokine gene expression in isolated rabbit lungs. Br J Anaesth 2004;92:558-63.

42. Leite CF, Calixto MC, Toro IF, et al. Characterization of pulmonary and systemic inflammatory responses produced by lung re-expansion after one-lung ventilation. J Cardiothorac Vasc Anesth 2012;26:427-32.

43. Schilling T, Kozian A, Kretzschmar M, et al. Effects of propofol and desflurane anaesthesia on the alveolar inflammatory response to one-lung ventilation. $\mathrm{Br} \mathrm{J}$ Anaesth 2007;99:368-75.

44. Schilling T, Kozian A, Senturk M, et al. Effects of volatile and intravenous anesthesia on the alveolar and systemic inflammatory response in thoracic surgical patients. Anesthesiology 2011;115:65-74.

45. De Conno E, Steurer MP, Wittlinger M, et al. Anestheticinduced improvement of the inflammatory response to one-lung ventilation. Anesthesiology 2009;110:1316-26.

46. Mineo TC, Ambrogi V. Immune effects after uniportal nonintubated video-thoracoscopic operations. Video-assist Thorac Surg 2018;3:4.

47. Mineo TC, Sellitri F, Vanni G, et al. Immunological and Inflammatory Impact of Non-Intubated Lung Metastasectomy. Int J Mol Sci 2017;18:1466.

48. Jeon J, Sung S, Moon Y, et al. Comparison of early postoperative cytokine changes in patients undergoing intubated and non-intubated thoracic surgery: a randomized controlled trial. Interact Cardiovasc Thorac Surg 2021;32:343-50.

49. Liu R, Ishibe Y, Ueda M. Isoflurane-sevoflurane adminstration before ischemia attenuates ischemiareperfusion-induced injury in isolated rat lungs. Anesthesiology 2000;92:833-40.

50. Misthos P, Katsaragakis S, Milingos N, et al. Postresectional pulmonary oxidative stress in lung 
cancer patients. The role of one-lung ventilation. Eur J Cardiothorac Surg 2005;27:379-82; discussion 382-3.

51. Riddle PR, Berenbaum MC. Postoperative depression of the lymphocyte response to phytohaemagglutinin. Lancet 1967;1:746-8.

52. Akiyoshi T, Koba F, Arinaga S, et al. Impaired production of interleukin-2 after surgery. Clin Exp Immunol 1985;59:45-9.

53. Stevenson GW, Hall S, Rudnick SJ, et al. Halothane anesthesia decreases human monocyte hydrogen peroxide generation. Protection of monocytes by activation with gamma interferon. Immunopharmacol Immunotoxicol 1987;9:489-510.

54. Devlin EG, Clarke RS, Mirakhur RK, et al. Effect of four i.v. induction agents on T-lymphocyte proliferations to PHA in vitro. Br J Anaesth 1994;73:315-7.

55. Tønnesen E. Immunological aspects of anaesthesia and surgery--with special reference to NK cells. Dan Med Bull 1989;36:263-81.

56. Yeager MP, Colacchio TA, Yu CT, et al. Morphine inhibits spontaneous and cytokine-enhanced natural killer cell cytotoxicity in volunteers. Anesthesiology 1995;83:500-8.

57. Griffith CD, Rees RC, Platts A, et al. The nature of enhanced natural killer lymphocyte cytotoxicity during anesthesia and surgery in patients with benign disease and cancer. Ann Surg 1984;200:753-8.

58. Markovic SN, Knight PR, Murasko DM. Inhibition of interferon stimulation of natural killer cell activity in mice anesthetized with halothane or isoflurane. Anesthesiology 1993;78:700-6.

59. Markovic SN, Murasko DM. Neoadjuvant immunotherapy with interferon of the spontaneously metastasizing murine B16F10L melanoma. Int J Cancer 1990;45:788-94.

60. Markovic SN, Murasko DM. Role of natural killer and T-cells in interferon induced inhibition of spontaneous metastases of the B16F10L murine melanoma. Cancer Res 1991;51:1124-8.

61. Kutza J, Gratz I, Afshar M, et al. The effects of general anesthesia and surgery on basal and interferon stimulated natural killer cell activity of humans. Anesth Analg 1997;85:918-23.

62. Ju NY, Gao H, Huang W, et al. Therapeutic effect of inhaled budesonide (Pulmicort ${ }^{\circledR}$ Turbuhaler) on the inflammatory response to one-lung ventilation. Anaesthesia 2014;69:14-23.

63. Lee SK, Son BS, Hwang JJ, et al. The use of neutrophil elastase inhibitor in the treatment of acute lung injury after pneumonectomy. J Cardiothorac Surg 2013;8:69.

64. Bedetti B, Patrini D, Bertolaccini L, et al. Uniportal non- intubated thoracic surgery. J Vis Surg 2018;4:18.

65. Okuda K, Nakanishi R. The non-intubated anesthesia for airway surgery. J Thorac Dis 2016;8:3414-9.

66. Batihan G, Ceylan KC, Usluer O, et al. Video-Assisted Thoracoscopic Surgery vs Thoracotomy for Non-Small Cell Lung Cancer Greater Than $5 \mathrm{~cm}$ : Is VATS a feasible approach for large tumors? J Cardiothorac Surg 2020;15:261.

67. Sihoe ADL. Video-assisted thoracoscopic surgery as the gold standard for lung cancer surgery. Respirology 2020;25 Suppl 2:49-60.

68. Lee JG, Cho BC, Bae MK, et al. Thoracoscopic lobectomy is associated with superior compliance with adjuvant chemotherapy in lung cancer. Ann Thorac Surg 2011;91:344-8.

69. Zhi X, Gao W, Han B, et al. VATS lobectomy facilitates the delivery of adjuvant docetaxel-carboplatin chemotherapy in patients with non-small cell lung cancer. J Thorac Dis 2013;5:578-84.

70. Petersen RP, Pham D, Burfeind WR, et al. Thoracoscopic lobectomy facilitates the delivery of chemotherapy after resection for lung cancer. Ann Thorac Surg 2007;83:12459; discussion 1250 .

71. Teh E, Abah U, Church D, et al. What is the extent of the advantage of video-assisted thoracoscopic surgical resection over thoracotomy in terms of delivery of adjuvant chemotherapy following non-small-cell lung cancer resection? Interact Cardiovasc Thorac Surg 2014;19:656-60.

72. Furák J, Paróczai D, Burián K, et al. Oncological advantage of nonintubated thoracic surgery: Better compliance of adjuvant treatment after lung lobectomy. Thorac Cancer 2020;11:3309-16.

73. Xue W, Duan G, Zhang X, et al. Comparison of nonintubated and intubated video-assisted thoracoscopic surgeries of major pulmonary resections for lung cancer-a meta-analysis. World J Surg Oncol 2021;19:87.

74. Liu J, Cui F, Pompeo E, et al. The impact of nonintubated versus intubated anaesthesia on early outcomes of video-assisted thoracoscopic anatomical resection in non-small-cell lung cancer: a propensity score matching analysis. Eur J Cardiothorac Surg 2016;50:920-5.

doi: 10.21037/asj-21-64

Cite this article as: Paróczai D, Lantos J, Barta Z, Pécsy B, Ottlakán A, Szabó Z, Burián K. Immunological perspectives in thoracic surgery: a narrative review on the cellular and cytokine responses induced by thoracotomy and video-assisted thoracic surgery. AME Surg J 2022;2:18. 